\title{
PENGARUH PENAMBAHAN KARAGINAN UNTUK FORMULASI TEPUNG PUDING INSTAN
}

\section{The Effect of Addition Carrageenan for The Formulation of Instant Pudding Flour}

\author{
Muhamad Darmawan ${ }^{1 *}$, Rosmawaty Peranginangin ${ }^{1}$, Rizal Syarief ${ }^{2}$, \\ Indah Kusumaningrum ${ }^{3}$, dan Dina Fransiska ${ }^{1}$ \\ ${ }^{1}$ Balai Besar Penelitian dan Pengembangan Pengolahan Produk dan Bioteknologi Kelautan dan Perikanan, \\ JI. K.S. Tubun Petamburan VI, Jakarta Pusat, Indonesia \\ 2 Program Studi IImu Pangan, Institut Pertanian Bogor. Jl. Raya Dramaga, Gedung Andi Hakim Nasoetion, \\ Kampus IPB Darmaga Bogor, Jawa Barat, Indonesia \\ 3Jurusan IImu Pangan Fakultas Teknologi Pertanian Institut Pertanian Bogor. Jl. Raya Dramaga, \\ Gedung Andi Hakim Nasoetion, Kampus IPB Darmaga Bogor, Jawa Barat, Indonesia \\ * Korespondensi Penulis: m.darmawan22@gmail.com \\ Diterima: 12 Februari 2014; Disetujui: 23 Mei 2014
}

\begin{abstract}
ABSTRAK
Penelitian pengaruh penambahan karaginan untuk formulasi tepung puding instan telah dilakukan. Percobaan yang dilakukan adalah penentuan perbandingan kappa dan iota karaginan $(3: 1,2: 1,1: 1,1: 2,1: 3)$ untuk formulasi pembuatan tepung puding instan dan formulasi tepung puding instan berdasarkan perbandingan kappa dan iota karaginan yang terpilih. Dari variasi percobaan yang digunakan, perbandingan kappa dan iota karaginan 1:1 merupakan perbandingan yang paling baik untuk digunakan dalam formulasi tepung puding instan karena memiliki kekuatan gel yang mendekati kekuatan gel puding komersial serta nilai sineresis yang terendah. Perbandingan konsentrasi karaginan, mocaf dekstrin dan $\mathrm{KCl}$ dalam formulasi tepung puding instan tidak memberikan pengaruh yang nyata terhadap kekuatan gel maupun karakteristik sensori kenampakan, aroma dan rasa dari puding instan yang dihasilkan. Namun demikian, formulasi tepung puding instan memberikan pengaruh yang nyata untuk karakteristik tekstur puding instan yang dihasilkan. Berdasarkan analisis fisik (kekuatan gel) dan sensori (kenampakan, aroma, tekstur, dan rasa) didapatkan perlakuan terbaik yaitu penggunaan karaginan 1,23\%, perbandingan tepung mocaf-dekstrin $0,5: 0,5$ dan $\mathrm{KCl} 0,45$ gram.
\end{abstract}

KATAKUNCl: tepung puding instan, karaginan, mocaf-dekstrin, kekuatan gel

\section{ABSTRACT}

A study on the effect of addition carrageenan for the formulation of instant pudding flour has been done. The experiments in this research were determination of the ratio of kappa and iota karaginan used for the formulation of instant pudding flour (3:1, 2:1, 1:1, 1:2,1:3) and the formulation of instant pudding flour based on the ratio of kappa and iota carrageenan. Results showed that the ratio of kappa and iota carrageenan (1:1) was the best ratio to be used for the formulation of instant pudding flour because it has gel strength value that was approaching the gel strength value of commercial pudding and it has the lowest syneresis value. The ratio of carrageenan, mocafdextrin and $\mathrm{KCl}$ didn't give significant effect to the gel strength and sensory characteristic like appearance, odor, and taste of pudding product. However, it gave significant effect to the texture characteristic of pudding product. Based on the physical and sensory analysis, the best pudding product was obtained from the use of $1.23 \%$ carrageenan, mocaf-dextrin ratio $0.5: 0.5$ and 0.45 gram $\mathrm{KCl}$ in the formulation.

\section{KEYWORDS: instant pudding flour, carrageenan, mocaf dextrin, gel strength}

\section{PENDAHULUAN}

Indonesia merupakan salah satu negara penghasil rumput laut terbesar di dunia. Kementerian Kelautan dan Perikanan (KKP) terus berupaya menggenjot sektor hulu rumput laut dengan menargetkan produksi rumput laut basah sebanyak 10 juta ton atau setara 1 juta ton rumput laut kering pada 2014. Target itu naik dua kali lipat dibanding realisasi 2012 yang hanya 5 juta ton dan naik $42 \%$ dari target tahun 2013 yang 
mencapai7juta ton (Anon., 2013). Rumput laut menghasilkan 3 jenis polimer karbohidrat yang dapat dimanfaatkan secara komersial. Ketiga polimer karbohidrat tersebut adalah alginat, agar, dan karaginan (Selby \& Whistler, 1993; De Ruiter \& Rudolph, 1997). Beberapa jenis rumput laut penghasil agar-agar diantaranya adalah Gracilaria sp., Gelidium sp., Gellidiella sp., dan jenis rumput laut penghasil karaginan adalah Eucheuma sp., Eucheuma cottonii sedangkan jenis rumput laut penghasil alginat adalah Sargassum sp. dan Turbinaria sp. (Istini \& Zatnika, 1991). Jenis rumput laut yang berkembang di Indonesia adalah jenis rumput laut merah (Rhodophyceae) dan rumput laut coklat (Phaeophyceae). Sebagian besar produksi rumput laut budidaya yang dihasilkan di Indonesia merupakan jenis Eucheuma cottonii dan Eucheuma spinosum sebagai penghasil karaginan. Karaginan merupakan nama umum dari polisakarida yang dihasilkan melalui ekstraksi beberapa spesies rumput laut merah (Rhodophyta) (Van De Velde et al., 2002). Polisakarida ini dapat dibagi menjadi 6 bentuk dasar utama yaitu lota- ( 1$),$ Kappa- $(\kappa)$, Lambda- $(\lambda)$, Mu- $(\mu)$, Nu- $(v)$ dan Theta- $(\theta)$ karaginan. Nomenklatur ini berlaku baik untuk klasifikasi kimia maupun untuk produksi komersial dari karaginan tersebut (Campo et al., 2009). Menurut Pereira et al. (2009), karaginan komersial biasanya dibagi ke dalam 3 tipe utama yaitu kappa-, iota- dan lambda-karaginan. Kappa karaginan memiliki kemampuan membentuk gel yang tinggi tetapi memiliki kencenderungan untuk mengalami sineresis. Iota karaginan memiliki kemampuan pembentukan gel yang lemah. Lambda karaginan memiliki kemampuan untuk membentuk larutan dengan viskositas tinggi (Hillou et al., 2012). Saat ini jenis kappa-karagenan dihasilkan dari rumput laut tropis jenis Kappaphycus alvarezii, yang di dunia perdagangan dikenal sebagai Eucheuma cottonii. Eucheuma denticulatum (dengan nama dagang Eucheuma spinosum) adalah spesies utama yang menghasilkan iota-karaginan. Lamda-karaginan diproduksi dari rumput laut jenis Gigartina dan Condrus (Van de Velde et al., 2002).

Karaginan banyak sekali digunakan dalam bidang industri baik pangan maupun non pangan. Karaginan memiliki sifat-sifat fungsional fisik yang sangat baik diantaranya mampu berperan sebagai bahan pengental dan memiliki kemampuan sebagai pembentuk gel dan stabilizer (Campo et al., 2009), sehingga banyak digunakan dalam proses pengolahan coklat, susu, puding dan makanan kaleng. Karaginan juga banyak digunakan pada berbagai macam produk non pangan seperti produk farmasi, kosmetik serta formulasi untuk textile printing (Imeson, 2000).

Salah satu produk yang dapat dihasilkan dengan menggunakan karaginan adalah puding. Puding merupakan salah satu jenis hidangan penutup yang pada umumnya disajikan pada akhir suatu jamuan makan. Sebagai makanan penutup, puding banyak diminati karena rasanya yang manis dan teksturnya yang lembut. Puding banyak dipasarkan dalam bentuk tepung puding instan sebagai salah satu bentuk pangan instan. Pangan instan merupakan bahan makanan yang dipekatkan atau berada dalam bentuk konsentrat. Cara menyiapkan pangan berbentuk instan hanya dengan menambah air (panas/dingin) sehingga siap disantap (Hartomo \& Widiatmoko, 1993). Dalam pembuatan puding, karaginan berfungsi untuk mengontrol viskositas dan tekstur puding (Campo et al., 2009). Puding komersial dibuat dari campuran pati, protein (susu), dan gula dengan pengadukan terus menerus di bawah api sedangtinggi. Bahan dasar yang biasa dipakai pada pembuatan puding adalah tepung tapioka atau pati termodifikasi, susu, whey powder, gula, karaginan, atau kadang-kadang juga gelatin (Anon., 2009).

Pati merupakan bahan hidrokoloid yang paling banyak digunakan dalam pembuatan puding (Dickinson, 2003). Menurut Hustiany (2006), jenis pati yang banyak dipakai pada pembuatan tepung puding instan adalah pati pregelatinisasi karena mempunyai sifat larut dalam air dingin dan dapat berperan sebagai bahan pengisi. Banyaknya pati pregelatinisasi yang dicampurkan pada pembuatan tepung puding instan berkisar antara 5-25\% (tetapi yang paling disukai antara $10-20 \%$ ) dari berat campuran tepung puding. Selain pati pregelatinisasi tapioka, bahan lainnya yang banyak dipakai dalam campuran pembuatan tepung puding instan adalah dekstrin dan tepung mocaf. Dalam campuran produk pangan tepung mocaf mempunyai sifat sebagai pengikat, pengental, dan pengisi. Aplikasinya dapat digunakan dalam berbagai industri sup, puding, makanan bayi, sosis, dan lain sebagainya. Dekstrin, dibuat dari pati melalui proses enzimatik atau proses asam yang disertai perlakuan pemanasan. Dekstrin bersifat sangat larut dalam air panas atau dingin, dengan viskositas yang relatif rendah. Sifat tersebut mempermudah penggunaan dekstrin apabila digunakan dalam konsentrasi yang cukup tinggi (Anon., 2006).

Menurut Subaryono et al. (2003), produk gel yang disimpan pada suhu rendah seperti puding dan jeli memerlukan sifat kekuatan gel tinggi dan sineresis rendah. Sineresis yang tinggi pada produk gel akan menyebabkan gel menjadi mengkerut atau kering selama penyimpanan. Kekuatan gel puding dapat mempengaruhi tingkat penerimaan konsumen. Puding yang memiliki kekuatan gel yang rendah menghasilkan puding menjadi lembek sehingga tingkat penerimaan konsumen menjadi menurun. 
Penggunaan karaginan dalam formula tepung puding berpotensi dapat memperbaiki mutu puding instan yang dihasilkan. Dua jenis karaginan yang dapat digunakan dalam aplikasi pembuatan puding adalah kappa dan iota karaginan. Hal ini berkaitan dengan sifat fungsional yang berbeda dari masing-masing karaginan tersebut. Kappa karaginan memiliki sifat kekuatan gel yang tinggi dan mudah mengalami sineresis, sedangkan iota karaginan mempunyai sifat kekuatan gel yang rendah dan tidak mudah mengalami sineresis. Penelitian ini bertujuan untuk mengetahui pengaruh penambahan campuran karaginan (kappa dan iota) untuk formulasi tepung puding instan terhadap mutu puding yang dihasilkan.

\section{BAHAN DAN METODE}

\section{Bahan}

Bahan baku yang digunakan dalam penelitian ini adalah ATC (Alkali Treated Cottonii) dari rumput laut E. cottonii sebagai bahan untuk pembuatan kappa karaginan dan rumput laut $E$. spinosum sebagai bahan utama pembuatan iota karaginan. Bahan lainnya yang digunakan adalah $\mathrm{NaOH}, \mathrm{KCl}$, celite, susu bubuk full krim, dekstrin, tepung mocaf, puding komersial, gula halus, perisa, garam, dan pewarna makanan.

\section{Metode}

Penelitian ini terdiri dari 3 tahap, yaitu tahap I pembuatan kappa dan iota karaginan serta karakterisasi sifat fisiko kimianya. Tahap II penentuan perbandingan kappa dan iota karaginan untuk formulasi pembuatan tepung puding instan. Tahap III formulasi tepung puding instan berdasarkan perbandingan kappa dan iota karaginan yang terpilih.

\section{Pembuatan kappa dan iota karaginan serta karakterisasi sifat fisiko kimianya}

Pembuatan kappa dan iota karaginan dilakukan dengan menggunakan modifikasi metoda yang digunakan Purnama (2003). Proses pembuatan kappa karaginan bisa dilakukan dengan cara ekstraksi rumput laut utuh jenis $E$. cottonii atau dengan menggunakan chips ATC. Dalam penelitian ini, bahan baku yang digunakan adalah chips ATC. Pembuatan iota karaginan pada penelitian ini dengan cara ekstraksi rumput laut utuh jenis E. spinosum. Diagram alir pembuatan kappa dan iota karaginan dapat dilihat pada Gambar 1.

Karakterisasi sifat fisiko kimia karaginan dilakukan untuk mengetahui sifat bahan baku karaginan baik kappa maupun iota yang dihasilkan. Dari karaginan (kappa dan iota) yang diperoleh kemudian dilakukan pengamatan yang meliputi rendemen, kadar air, kadar abu, dan kadar abu tidak larut asam (AOAC, 1999), kadar sulfat, viskositas, dan kekuatan gel (FMC corp, 1977).

\section{Penentuan perbandingan kappa dan iota karaginan untuk formula pembuatan tepung puding instan}

Penelitian selanjutnya adalah percobaan kombinasi kappa dan iota karaginan dengan perbandingan $1: 1,1: 2,1: 3,2: 1$ dan $3: 1$ untuk mendapatkan perbandingan karaginan (kappa dan iota) yang tepat untuk diaplikasikan pada pembuatan tepung puding instan. Pengamatan yang dilakukan adalah kekuatan gel dan sineresis dari campuran yang dihasilkan. Rancangan percobaan yang digunakan untuk melihat pengaruh campuran karaginan (kappa dan iota) penelitian ini adalah Rancangan Acak Lengkap (RAL) dengan 3 kali ulangan (Steel \& Torrie, 1993).

\section{Formulasi tepung puding instan berdasarkan perbandingan kappa dan iota karaginan yang terpilih}

Setelah diperoleh perbandingan campuran karaginan (kappa dan iota) yang tepat (butir 2) kemudian dilakukan pengukuran nilai kekuatan gel tepung puding komersial. Campuran kappa dan iota yang digunakan untuk formulasi adalah campuran kappa dan iota yang memiliki nilai kekuatan gel yang menyerupai kekuatan gel pudding instan komersial serta memiliki nilai sineresis yang rendah.

Proses formulasi pembuatan tepung puding instan dilakukan dengan mencampurkan semua bahan yang diperlukan dalam pembuatan tepung puding instan seperti susu, mocaf, dekstrin, karaginan, $\mathrm{KCl}$, gula dan perisa. Komponen bahan terbesar dalam formulasi yang digunakan adalah penggunaan tepung mocafdekstrin dan susu. Pengamatan yang dilakukan adalah kekuatan gel (FMC corp, 1977) dan pengujian sensori yaitu uji hedonik oleh panelis semi-terlatih sebanyak 15 orang meliputi kenampakan, aroma, tekstur dan rasa dari puding instan yang dihasilkan dengan skala katagori 1-7 dengan deskripsi sebagai berikut: $1=$ sangat tidak suka , $2=$ tidak suka, $3=$ agak tidak suka , $4=$ netral , $5=$ agak suka , $6=$ suka dan $7=$ sangat suka. Rancangan percobaan yang digunakan untuk melihat pengaruh perbandingan campuran kappa dan iota karaginan (1:1) sebanyak $0,8 \%, 1 \%$, $1,23 \%$, Perbandingan tepung mocaf-dekstrin $(0: 100$; $25: 75 ; 0,5: 0,5)$ dan $\mathrm{KCl}(0$ dan $0,45 \mathrm{~g})$ pada formulasi tepung puding instan adalah Rancangan Acak 


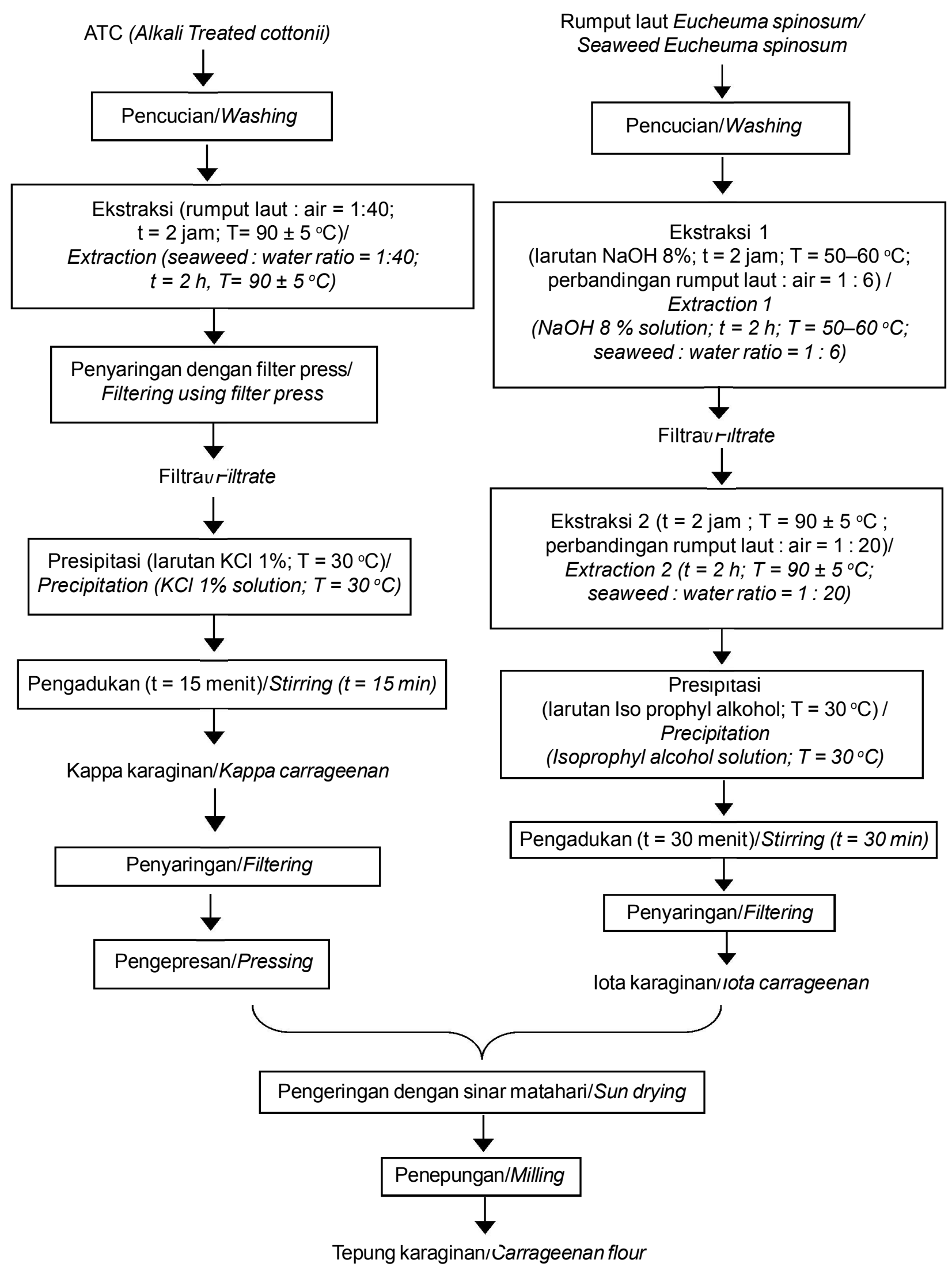

Gambar 1. Diagram alir pembuatan kappa dan iota karaginan.

Figure 1. Flow chart of production of kappa and iota carrageenan. 
Tabel 1. Karakteristik fisiko kimia kappa dan iota karaginan yang digunakan dalam penelitian Table 1. Characteristic of kappa and iota carrageenan used in the experiment

\begin{tabular}{lccc}
\hline \multicolumn{1}{c}{ Parameter/Parameters } & $\begin{array}{c}\text { Kappa karaginan/ } \\
\text { Kappa carrageenan }\end{array}$ & $\begin{array}{c}\text { lota karaginan/ } \\
\text { lota carrageenan }\end{array}$ & $\begin{array}{c}\text { standar FAO/ } \\
\text { FAO standard }\end{array}$ \\
\hline Rendemen/Yield (\%) & $32.98 \pm 6.80$ & $14.23 \pm 1.80$ & - \\
Kadar Air/Moisture content (\%) & $8.25 \pm 0.07$ & $13.04 \pm 1.11$ & maks/max 12 \\
Kadar Abu/Ash content (\%) & $27.33 \pm 0.71$ & $22.66 \pm 0.29$ & $15-40$ \\
Kadar Abu tak larut asam/ Acid & $0.27 \pm 0.08$ & $0.18 \pm 0.06$ & maks/max 1 \\
insoluble ash content (\%) & $17.69 \pm 0.25$ & $30.00 \pm 0.36$ & $15-40$ \\
Kadar Sulfat/Sulphate content (\%) & $31.00 \pm 2.12$ & $394.25 \pm 20.15$ & - \\
Viskositas/Viscosity (cPs) & $1616 \pm 35.85$ & $96 \pm 5.51$ & - \\
Kekuatan gel/Gel strength (gr/cm ${ }^{2}$ ) & & & \\
\hline
\end{tabular}

Keterangan/Note: (-) tidak ada syarat dalam Standar FAO/ there is no requirement in the FAO Standard

Lengkap Faktorial (RALF) dengan 3 kali ulangan (Steel \& Torrie, 1993).

\section{HASIL DAN PEMBAHASAN}

\section{Sifat Fisiko Kimia Kappa dan lota Karaginan}

Karakterisasi sifat fisiko kimia kappa dan iota karaginan yang dilakukan meliputi rendemen, kadar air, kadar abu, kadar abu tak larut asam, kadar sulfat, viskositas dan kekuatan gel. Nilai parameter fisiko kimia dari kappa dan iota karaginan yang dihasilkan dapat dilihat pada Tabel 1.

\section{Rendemen}

Rata-rata rendemen kappa dan iota karaginan yang dihasilkan pada penelitian ini berkisar antara 32,98 \pm $6,80 \%$ dari berat ATC dan $14,23 \pm 1,80 \%$ dari berat rumput laut kering. Nilai rata-rata rendemen kappa karaginan yang dihasilkan masih lebih tinggi dibandingkan dengan nilai rendemen karaginan yang dilaporkan oleh Hakim et al. (2011) yaitu 21,76$31,77 \%$. Namun demikian, rendemen iota karaginan yang dihasilkan dalam penelitian ini masih lebih rendah dibandingkan dengan rendemen karaginan hasil penelitian Purnama (2003) yang menggunakan perbandingan air $1: 40$ yaitu $20,20 \%$. Dari hasil tersebut dapat diketahui bahwa rendemen karaginan yang dihasilkan dapat dipengaruhi oleh faktor teknik ekstraksi seperti perbandingan air yang digunakan untuk mendapatkan karaginan. Di samping itu, hasil penelitian lain juga menunjukkan bahwa rendemen karaginan juga dapat dipengaruhi oleh waktu dan suhu ekstraksi serta konsentrasi alkali yang digunakan dalam proses ekstraksi karaginan (Istini \& Zatnika, 1991; Basmal et al., 2009)

\section{Kadar air}

Kadar air kappa karaginan yang dihasilkan berkisar $8,25 \pm 0,07 \%$ dari berat ATC dan iota karaginan 13,04 $\pm 1,11 \%$ dari berat rumput laut kering. Kadar air kappa karaginan masih memenuhi persyaratan kadar air karaginan yang ditetapkan oleh FAO (2007) yaitu maksimum $12 \%$, sedangkan kadar air iota karaginan yang dihasilkan tidak memenuhi standar kadar air dari FAO. Kadar air karaginan yang dihasilkan dapat dipengaruhi oleh beberapa faktor, diantaranya adalah jenis dan umur rumput laut yang digunakan serta teknik ekstraksi yang dipakai dalam pembuatan karaginan. Selain itu, teknik pengeringan yang digunakan menjadi faktor penting yang mempengaruhi kadar air karaginan yang dihasilkan.

\section{Kadarabu}

Nilai kadar abu suatu bahan pangan menunjukkan besarnya jumlah mineral yang terkandung dalam bahan pangan tersebut (Apriyantono et al., 1989). Standar FAO (2007) untuk kadar abu karaginan adalah 15$40 \%$, sedangkan menurut FCC (Food Chemical Codex) (1981) kadar abu karaginan yaitu maksimal 35\%. Hasil penelitian menunjukkan bahwa kadar abu kappa karaginan $27,33 \pm 0,71 \%$ dari berat ATC dan $22,66 \pm$ $0,29 \%$ dari berat rumput laut kering. Bila dibandingkan dengan kedua standar di atas maka kadar abu karaginan baik kappa maupun iota masih masuk 
dalam standar kadar abu tersebut. Kadar abu kappa karaginan lebih tinggi dibandingkan dengan kadar abu dari iota karaginan, disebabkan oleh teknik ekstraksi yang digunakan. Pembuatan kappa karaginan menggunakan $\mathrm{KCl}$ dalam proses ekstraksinya. Selain itu untuk mendapatkan ATC sebagai bahan baku kappa karaginan digunakan bahan kimia yaitu $\mathrm{KOH}$. Penggunaan $\mathrm{KOH}$ dan $\mathrm{KCl}$ dapat meningkatkan kadar abu karaginan yang dihasilkan. Basmal et al. (2003) menyatakan bahwa kadar abu kappa karaginan akan semakin meningkat seiring dengan peningkatan $\mathrm{KOH}$ yang digunakan dalam proses ektraksi. Di samping itu, adanya ion Kalium dalam $\mathrm{KCl}$ pada proses presipitasi karaginan akan meningkatkan kadar abu karaginan yang dihasilkan.

Kadar abu tak larut asam kappa dan iota karaginan yang dihasilkan adalah $0,27 \pm 0,08 \%$ dan $0,18 \pm$ $0,06 \%$. Abu tidak larut asam adalah garam-garam klorida yang tidak larut asam yang sebagian adalah garam-garam logam berat dan silika. Kadar abu tidak larut asam merupakan salah satu kriteria dalam menentukan tingkat kebersihan dalam proses pengolahan (Basmal et al., 2003) dan biasanya digunakan untuk melihat adanya kontaminasi bahan yang mengandung logam. Kadar abu tidak larut asam yang dihasilkan masih di bawah standar kadar abu tak larut asam yang dipersyaratkan oleh FAO (2007) dan FCC (1981) yaitu 1\%. Hal ini menandakan bahwa karaginan yang dihasilkan pada penelitian ini tidak mengalami banyak kontaminasi dari bahan-bahan logam yang mungkin terdapat dalam bahan baku selama proses penanganannya maupun pada saat proses ekstraksi karaginan.

\section{Kadar sulfat}

Kadar sulfat kappa dan iota karaginan adalah $17,69 \pm 0,25 \%$ dan $30,00 \pm 0,36 \%$. Kadar sulfat kappa maupun iota karaginan yang dihasilkan masih masuk dalam standar kadar sulfat yang dikeluarkan oleh FAO (2007) dan FCC (1981) yaitu 15-40\% dan 18-40\%. Kadar sulfat iota karaginan lebih tinggi dibandingkan dengan kadar sulfat kappa karaginan. Menurut Glicksman (1983) iota karaginan memiliki ester sulfat lebih tinggi dibandingkan dengan ester sulfat dari kappa karaginan. Ester sulfat iota karaginan berkisar antara $28-35 \%$ sedangkan ester sulfat kappa karaginan berkisar antara 25-30\%. Kandungan sulfat untuk kappa, iota, dan lambda karaginan komersial adalah $22 \%(\mathrm{w} / \mathrm{w}), 32 \%(\mathrm{w} / \mathrm{w})$, dan 38\% (w/w). Nilai tersebut di atas masih bisa bervariasi tergantung dari jenis rumput laut yang digunakan (De Ruiter \& Rudolph, 1997).

Penggunaan larutan $\mathrm{NaOH} 8 \%$ pada pembuatan iota karaginan dan larutan $\mathrm{KOH} 8 \%$ pada pembuatan ATC yang digunakan sebagai bahan baku pembuatan kappa karaginan dalam penelitian ini dapat mempengaruhi kadar sulfat karaginan yang dihasilkan. Transformasi gugus sulfat yang terikat dalam gugus galaktosa oleh ion $\mathrm{Na}^{+}$akan membentuk garam $\mathrm{Na}_{2} \mathrm{SO}_{4}$, kemudian akan terjadi dehidrasi membentuk polimer anhidros galaktosa, dimana ion $\mathrm{H}^{+}$dari larutan alkali bereaksi dengan ikatan bergugus $\mathrm{H}$ membentuk karaginan dan air (Distantina et al., 2009). Hasil penelitian Basmal et al. (2003) menunjukkan bahwa penggunaan $\mathrm{KOH} 6 \%$ dalam pembuatan karaginan menghasilkan kadar sulfat yang lebih rendah dibandingkan dengan penggunaan $\mathrm{KOH} 12 \%$.

\section{Viskositas dan kekuatan gel}

Pengujian viskositas dilakukan untuk mengetahui tingkat kekentalan suatu larutan yang dinyatakan dengan centipoises (cPs). Terdapat hubungan antara kadar sulfat, viskositas dan kekuatan gel dari karaginan. Menurut Basmal et al. (2005), semakin tinggi kandungan sulfat maka kekuatan gel akan semakin rendah tetapi nilai kekentalan menjadi tinggi. Viskositas kappa karaginan pada penelitian ini adalah $31,00 \pm 2,12 \mathrm{cPs}$, sedangkan viskositas iota karaginan adalah 394,25 $\pm 20,15$ cPs. Sementara itu, kekuatan gel kappa karaginan yang didapat pada penelitian ini adalah $1.616 \pm 35,85 \mathrm{~g}$, sedangkan kekuatan gel iota karaginan yaitu $96 \pm 5,51 \mathrm{~g}$. Dari hasil di atas, diketahui bahwa nilai viskositas berbanding terbalik dengan nilai kekuatan gel yang dihasilkan baik untuk kappa karaginan maupun iota karaginan.

Bila dilihat dari kadar sulfat yang dihasilkan di atas maka terdapat korelasi antara kadar sulfat dengan viskositas dan kekuatan gel karaginan yang di dapat baik untuk kappa maupun iota karaginan. Kadar sulfat dan viskositas kappa karaginan lebih rendah bila dibandingkan dengan kadar sulfat dan viskositas iota karaginan. Di samping itu, rendahnya kadar sulfat pada kappa karaginan berdampak pada tingginya kekuatan gel yang didapatkan. Sementara itu, tingginya kadar sulfat pada iota karaginan berdampak pada rendahnya kekuatan gel yang dihasilkan. Menurut Campo et al. (2009), proporsi fraksi sulfat dapat menentukan nilai viskositas dan kekuatan gel karaginan. Hasil penelitian dari Suryaningrum (1988) juga menunjukkan bahwa semakin tinggi kandungan sulfat maka nilai viskositas juga semakin tinggi, tetapi konsistensi gelnya akan semakin menurun pada iota karaginan.

\section{Perbandingan Kappa dan lota Karaginan untuk Tepung Puding Instan}

Tekstur dan rasa dari puding merupakan faktor yang penting untuk diperhatikan dalam pembuatan puding. Perbandingan kappa dan iota karaginan yang tepat 
diharapkan mampu untuk memperbaiki tekstur puding instan yang dihasilkan. Menurut Novianti (2003), kombinasi kappa dan iota karaginan dapat meningkatkan elastisitas gel dan mencegah sineresis produk. Kombinasi perbandingan kappa dan iota karaginan yang digunakan dalam penelitian ini adalah adalah $1: 1 ; 1: 2 ; 1: 3 ; 2: 1$; dan $3: 1$.

\section{Kekuatan Gel Campuran Karaginan}

Kekuatan gel dari campuran kappa dan iota karaginan yang dihasilkan berkisar antara 172,561792,739 g. Kekuatan gel tertinggi dihasilkan oleh campuran kappa dan iota karaginan dengan perbandingan 2:1 dan kekuatan gel terendah dihasilkan oleh campuran kappa dan iota karaginan dengan perbandingan 1:3. Hasil analisis ragam menunjukkan bahwa perbandingan kappa dan iota karaginan memberikan pengaruh yang nyata $(p<0,05)$ terhadap kekuatan gel yang dihasilkan. Kekuatan gel campuran karaginan dapat dilihat pada Gambar 2.

Kappa dan iota karaginan merupakan fraksi yang mampu membentuk gel dalam air dan bersifat thermo reversible yang meleleh jika dipanaskan dan membentuk gel kembali jika didinginkan. Kappa karaginan sensitif terhadap ion kalium dan akan membentuk gel yang kuat dengan adanya garam kalium (Glicksman, 1983), sedangkan iota karaginan membentuk gel yang kuat apabila ada ion $\mathrm{Ca}^{2+}$ (Angka \& Suhartono, 2000). Konsistensi gel dipengaruhi oleh beberapa faktor diantaranya jenis dan tipe karaginan, konsentrasi dan adanya ion-ion pengikat yang menghambat pembentukan hidrokoloid. Selain itu kekuatan gel juga dipengaruhi oleh letak gugus sulfat pada strukturnya.

Dari Gambar 2 dapat dilihat bahwa semakin banyak penggunaan kappa karaginan di dalam campuran

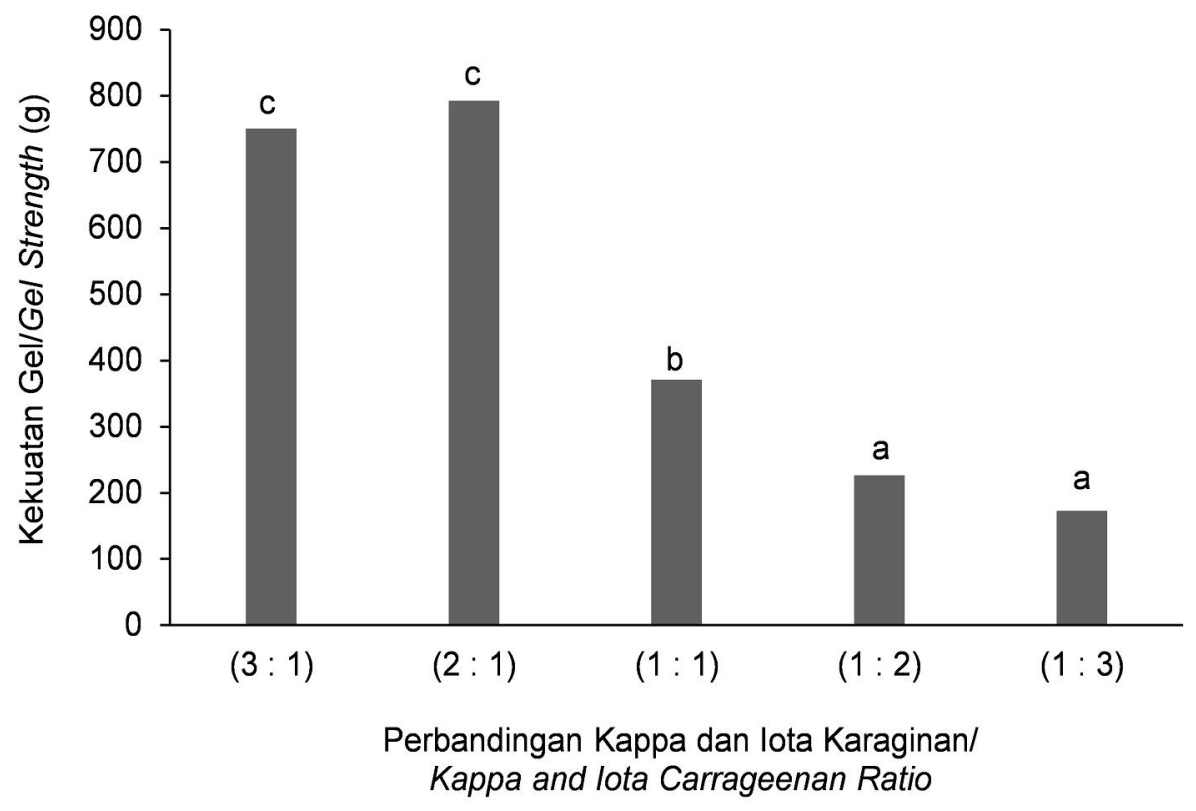

Keterangan/Note:

$(3: 1)=$ Perbandingan kappa dan iota karaginan sebesar $3: 1 /$ Ratio of kappa and iota carrageenan $3: 1$

$(2: 1)$ = Perbandingan kappa dan iota karaginan sebesar $2: 1 /$ Ratio of kappa and iota carrageenan $2: 1$

$(1: 1)$ = Perbandingan kappa dan iota karaginan sebesar $1: 1 /$ Ratio of kappa and iota carrageenan 1:1

$(1: 2)=$ Perbandingan kappa dan iota karaginan sebesar $1: 2 /$ Ratio of kappa and iota carrageenan $1: 2$

$(1: 3)$ = Perbandingan kappa dan iota karaginan sebesar $1: 3 /$ Ratio of kappa and iota carrageenan $1: 3$

Gambar 2. Pengaruh perbandingan kappa dan iota karaginan terhadap kekuatan gel campuran kappa dan iota karaginan.

Figure 2. Effect of kappa and iota carrageenan on gel strength of kappa and iota mixture. 
maka kekuatan gel yang dihasilkan semakin meningkat, demikian pula sebaliknya apabila penggunaan iota karaginan semakin banyak di dalam campuran maka kekuatan gel yang dihasilkan akan semakin menurun. Dari hasil tersebut dapat terlihat bahwa kappa karaginan menghasilkan kekuatan gel yang tinggi dibandingkan dengan iota karaginan. Dengan demikian karaginan E. cottonii memiliki kekuatan gel yang lebih tinggi dibandingkan dengan kekuatan gel dari $E$. spinosum. Gel karaginan $E$. spinosum (iota karaginan), bersifat tidak keras, lembut, elastis dan cenderung stabil tanpa sineresis (Diharmi et al., 2011). Menurut Angka dan Suhartono (2000), kappa karaginan membentuk gel yang keras dan elastis. Dari semua karaginan, kappa karaginan memberikan gel yang paling kuat. Perbedaan utama antara kappa dan iota karaginan adalah adanya gugus 2-sulfat pada gugus 3,6 anhydro D-galactosa pada iota karaginan yang mempengaruhi sensitivitas terhadap ion kalium. Peningkatan gugus 2-sulfat hingga $25-50 \%$ menyebabkan sensitivitas terhadap ion kalium yang juga mengakibatkan penurunan kekuatan gel yang terbentuk (Glicksman, 1983).

\section{Sineresis Campuran Karaginan}

Dari hasil analisis sineresis menunjukkan bahwa perbandingan kappa dan iota berpengaruh nyata terhadap sineresis gel karaginan $(p<0,05)$. Kombinasi karaginan yang memiliki nilai sineresis paling tinggi adalah karaginan dengan perbandingan kappa-iota (3:1). Sedangkan campuran karaginan dengan perbandingan kappa-iota karaginan (1:1) mempunyai tingkat sineresis yang paling rendah (Gambar 3 ).

Sineresis adalah karakteristik yang dapat dilihat berupa terjadinya pengkerutan gel yang bersifat

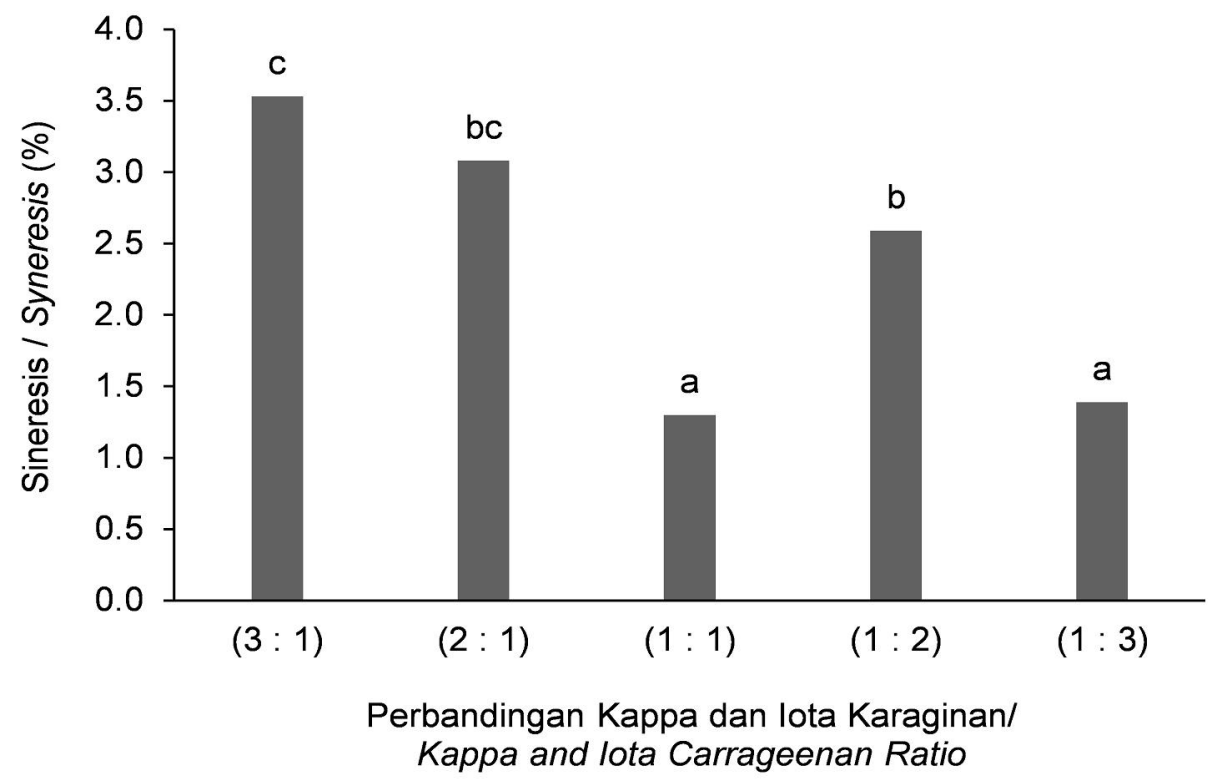

Keterangan/Note:

$(3: 1)=$ Perbandingan campuran kappa dan iota karaginan sebesar $3: 1 /$ Ratio of kappa and iota carrageenan mixture $3: 1$

$(2: 1)=$ Perbandingan campuran kappa dan iota karaginan sebesar $2: 1 /$ Ratio of kappa and iota carrageenan mixture $2: 1$

$(1: 1)=$ Perbandingan campuran kappa dan iota karaginan sebesar $1: 1 /$ Ratio of kappa and iota carrageenan mixture $1: 1$

$(1: 2)$ = Perbandingan campuran kappa dan iota karaginan sebesar $1: 2$ / Ratio of kappa and iota carrageenan mixture $1: 2$

$(1: 3)=$ Perbandingan campuran kappa dan iota karaginan sebesar $1: 3 /$ Ratio of kappa and iota carrageenan mixture $1: 3$

Gambar 3. Pengaruh perbandingan kappa dan iota karaginan terhadap sineresis campuran kappa dan iota karaginan

Figure 3. Effect of kappa and iota carrageenan on syneresis of kappa and iota mixture. 
lambat, dipengaruhi waktu dengan hasil terlepasnya cairan dari gel. Sineresis dalam suatu gel terlihat dari banyaknya air yang dilepaskan gel oleh pengaruh penyimpanan. Semakin besar nilai sineresis menunjukkan gel semakin mudah melepaskan air dan biasanya kurang disukai dalam perdagangan. Sineresis yang terjadi selama penyimpanan diamati dengan menyimpan masing-masing puding pada suhu refrigerator $\left(10^{\circ} \mathrm{C}\right)$ selama 24 jam.

Dari Gambar 3 diketahui bahwa nilai sineresis perbandingan campuran kappa dan iota karaginan yang dihasilkan berfluktuatif. Dari grafik dapat dilihat adanya kecenderungan penurunan nilai sineresis seiring dengan penurunan jumlah kappa karaginan yang digunakan di dalam campuran. Sementara itu, untuk peningkatan jumlah iota karaginan pada campuran, nilai sineresis yang dihasilkan tidak berbeda nyata untuk perbandingan kappa dan iota karaginan sebanyak 1:1 dan 1:3. Fluktuasi hanya terjadi pada nilai sineresis untuk perbandingan kappa dan iota karaginan sebanyak 1:2.

Kappa karaginan memiliki sifat gel yang rigid (mudah pecah) hal ini ditandai dengan tingkat sineresis yang tinggi sedangkan iota karaginan mempunyai gel yang elastis dan tidak mudah mengalami sineresis. Sedangkan campuran karaginan mempunyai gel dari yang mudah pecah (rigid) sampai gel yang elastis atau sedikit elastis. Sifat rigid yang dihasilkan pada gel kappa karaginan meningkat sesuai dengan peningkatan konsentrasi ion kalium, sedangkan penambahan ion kalsium akan membuat gel dari kappa karaginan memiliki sifat rigid namun rapuh atau mudah pecah (Novianti, 2003). Hal ini dapat dikontrol atau dihilangkan dengan mencampur kappa karaginan dengan bahan yang tidak mengalami sineresis seperti iota karaginan. Kombinasi iota karaginan dengan kappa karaginan dapat meningkatkan elastisitas gel dan mencegah sineresis.

\section{Formulasi Tepung Puding Instan}

Proporsi campuran kappa dan iota karaginan yang akan digunakan dalam formulasi tepung puding instan ditentukan berdasarkan nilai kekuatan gel yang paling mendekati kekuatan gel tepung puding instan komersial. Disamping itu, nilai sineresis yang rendah juga menjadi bahan pertimbangan dalam penentuan campuran kappa dan iota karaginan yang akan digunakan. Hal ini dilakukan karena belum adanya SNI Puding sehingga mengacu pada produk yang sudah ada dipasaran.

Perlakuan campuran kappa dan iota karaginan dengan perbandingan 1:1 memiliki nilai kekuatan gel yang mendekati kekuatan gel tepung puding komersial yaitu $400 \mathrm{~g} / \mathrm{cm}^{2}$. Disamping itu, nilai sineresis untuk campuran kappa dan iota karaginan dengan perbandingan 1:1 merupakan yang paling rendah dibandingkan dengan nilai sineresis perlakuan lainnya sehingga sangat baik untuk digunakan dalam formulasi tepung puding instan. Faktor lain yang dapat dijadikan pertimbangan adalah harga bahan kappa dan iota karaginan yang digunakan dalam produksi tepung puding instan dari campuran kappa dan iota karaginan.

Dengan mempertimbangkan hal tersebut di atas maka perbandingan campuran kappa dan iota karaginan yang digunakan dalam formulasi tepung puding instan adalah 1:1. Pengaruh konsentrasi karaginan, mocaf dekstrin dan $\mathrm{KCl}$ terhadap kekuatan gel dan sensori (kenampakan, aroma, tekstur dan rasa) puding yang dihasilkan dari tepung puding instan yang diformulasi dapat dilihat pada Tabel 2.

\section{Kekuatan Gel Puding}

Kekuatan gel (breaking force) adalah beban maksimum yang dibutuhkan untuk memecah matrik polimer pada daerah yang dibebani. Hasil uji sidik ragam menunjukkan bahwa penambahan tepung mocaf-dekstrin, karaginan dan $\mathrm{KCl}$ tidak memberikan pengaruh yang nyata terhadap peningkatan kekuatan gel $(p>0,05)$, sedangkan interaksi yang terjadi antara mocaf-dekstrin dan karaginan, mocaf-dekstrin dan $\mathrm{KCl}$, karaginan dan $\mathrm{KCl}$ memberikan pengaruh yang nyata terhadap kekuatan gel puding $(p<0,05)$. Semakin banyak konsentrasi karaginan yang ditambahkan, semakin sedikit konsentrasi perbandingan mocafdekstrin yang ditambahkan dan semakin banyak $\mathrm{KCl}$ yang ditambahkan maka kekuatan gel pudingnya akan semakin tinggi. Hal ini sesuai dengan percobaan yang dilakukan oleh Trckova et al. (2004) bahwa desserts yang terdiri dari campuran susu, karaginan mengalami peningkatan kekuatan gelnya, dengan semakin meningkatnya konsentrasi karaginan yang ditambahkan. Adanya interaksi antara karaginan dan protein susu sangat berpengaruh pada pembentukan sifat reologi dari gel karaginan itu sendiri (Trckova et al., 2004).

\section{Karakteristik Sensori Gel Puding}

Dalam industri pangan, kepuasan konsumen merupakan target utama yang harus dipenuhi apabila produsen ingin mendapatkan keuntungan. Kepuasan konsumen tercapai apabila produsen mampu menyediakan produk dengan mutu terbaik. Salah satu cara untuk mendapatkan produk dengan mutu terbaik yaitu dengan analisa sensori. Penilaian mutu secara sensori disukai karena dapat dilakukan secara cepat (Soekarto, 1985). Respon sensori didapatkan melalui uji rating hedonik menggunakan 15 panelis semi-terlatih. 
Tabel 2. Pengaruh konsentrasi karaginan (campuran kappa dan iota $1: 1$ ), campuran mocaf- dekstrin dan $\mathrm{KCl}$ terhadap kekuatan gel dan karakteristik sensori puding

Table 2. Effect of carrageenan concentration (kappa and iota carrageenan mixture 1: 1), mocaf-dextrin mixture and $\mathrm{KCl}$ on the gel strength and sensory characteristic of pudding

\begin{tabular}{|c|c|c|c|c|c|c|c|c|}
\hline \multirow{2}{*}{$\begin{array}{l}\text { Formulasi/ } \\
\text { Formulation }\end{array}$} & \multirow{2}{*}{$\begin{array}{c}\text { Perbandingan } \\
\text { Mocaf - } \\
\text { Dekstrin/ Mocaf } \\
\text { - Dextrin Ratio }\end{array}$} & \multirow{2}{*}{$\begin{array}{c}\text { Campuran Kappa } \\
\text { : lota=1:1 }(\% \\
\text { Mixture of } \\
\text { Kappa:lota=1:1) }\end{array}$} & \multirow{2}{*}{$\begin{array}{c}\mathrm{KCl} \\
\text { (gram) }\end{array}$} & \multirow{2}{*}{$\begin{array}{c}\text { Kekuatan } \\
\text { Force } \\
\left(\mathrm{gr} / \mathrm{cm}^{2}\right)\end{array}$} & \multicolumn{4}{|c|}{ Respon Sensori/Sensory's Respon } \\
\hline & & & & & $\begin{array}{l}\text { Kenampakan/ } \\
\text { Appearance }\end{array}$ & $\begin{array}{l}\text { Aroma/ } \\
\text { Flavour }\end{array}$ & $\begin{array}{l}\text { Tekstur/ } \\
\text { Texture }\end{array}$ & $\begin{array}{l}\text { Rasa/ } \\
\text { Taste }\end{array}$ \\
\hline 1 & $50: 50$ & 0.80 & 0.45 & 332.89 & 4.62 & 4.59 & 3.45 & 4.24 \\
\hline 2 & $25: 75$ & 0.80 & 0.45 & 486.06 & 4.53 & 4.77 & 3.67 & 4.21 \\
\hline 3 & $0: 100$ & 0.80 & 0.45 & 657.93 & 4.00 & 4.52 & 3.48 & 4.31 \\
\hline 4 & $50: 50$ & 1.00 & 0.45 & 236.09 & 5.60 & 5.27 & 4.20 & 5.20 \\
\hline 5 & $25: 75$ & 1.00 & 0.45 & 265.43 & 5.17 & 5.24 & 4.55 & 5.21 \\
\hline 6 & $0: 100$ & 1.00 & 0.45 & 414.23 & 4.93 & 5.27 & 4.24 & 5.00 \\
\hline 7 & $50: 50$ & 1.23 & 0.45 & 364.84 & 5.17 & 5.17 & 5.76 & 5.31 \\
\hline 8 & $25: 75$ & 1.23 & 0.45 & 470.82 & 5.23 & 5.40 & 5.38 & 4.97 \\
\hline 9 & $0: 100$ & 1.23 & 0.45 & 892.66 & 4.24 & 4.69 & 4.90 & 4.54 \\
\hline 10 & $50: 50$ & 0.80 & 0.00 & 151.78 & 5.27 & 5.60 & 4.60 & 4.73 \\
\hline 11 & $25: 75$ & 0.80 & 0.00 & 232.61 & 5.07 & 5.73 & 4.60 & 5.07 \\
\hline 12 & $0: 100$ & 0.80 & 0.00 & 323.60 & 4.87 & 5.93 & 4.40 & 5.00 \\
\hline 13 & $50: 50$ & 1.00 & 0.00 & 157.77 & 3.13 & 3.47 & 3.80 & 3.53 \\
\hline 14 & $25: 75$ & 1.00 & 0.00 & 204.46 & 5.80 & 5.47 & 4.53 & 4.87 \\
\hline 15 & $0: 100$ & 1.00 & 0.00 & 327.75 & 5.00 & 5.33 & 4.47 & 5.27 \\
\hline 16 & $50: 50$ & 1.23 & 0.00 & 228.19 & 5.73 & 5.27 & 5.47 & 5.27 \\
\hline 17 & $25: 75$ & 1.23 & 0.00 & 302.41 & 4.87 & 5.13 & 5.47 & 5.80 \\
\hline 18 & $0: 100$ & 1.23 & 0.00 & 412.06 & 5.40 & 5.40 & 5.40 & 5.47 \\
\hline
\end{tabular}

Keterangan/Note: *) \% campuran terhadap mocaf-dekstrin/\% mixture to mocaf-dextrin

Kenampakan merupakan karakteristik pertama yang dinilai panelis dalam mengkonsumsi suatu produk (Soekarto, 1985). Kenampakan merupakan salah satu faktor yang sangat mempengaruhi mutu dari suatu produk pangan. Hasil uji sidik ragam menunjukkan bahwa perbandingan konsentrasi mocaf-dekstrin, karaginan, $\mathrm{KCl}$ dan interaksi yang terjadi antara perbandingan konsentrasi mocaf- dekstrin dan karaginan, mocaf-dekstrin dan $\mathrm{KCl}$, karaginan dan $\mathrm{KCl}$ tidak memberikan pengaruh yang nyata terhadap penerimaan panelis terhadap kenampakan puding $(p>0,05)$. Hal ini menunjukkan bahwa penambahan konsentrasi karaginan, perbandingan konsentrasi mocaf-dekstrin dan $\mathrm{KCl}$ tidak memberikan efek yang nyata terhadap penilaian kesukaan panelis terhadap puding instan yang 
dihasilkan. Tingkat kesukaan panelis terhadap kenampakan puding yang dihasilkan berkisar antara agak tidak suka hingga suka.

Aroma dari suatu produk pangan merupakan salah satu parameter yang ikut menentukan kelezatan dari suatu produk pangan. Aroma dapat dikaitkan dengan keberadaan senyawa yang dapat menimbulkan kesan makanan tertentu dengan hanya dicium saja. Senyawa disebut sebagai senyawa penyumbang bau atau rasa. Aroma atau flavor merupakan kombinasi taste dan odoryang dipengaruhi oleh sensasi plain, panas, dingin dan rabaan. Untuk mendapatkan kesan flavor, ada banyak indra yang terlibat, seperti reseptor cicip, reseptor olfaktori, reseptor rabaan, termal (panas dan dingin) serta reseptor rasa sakit. Flavor atau aroma memiliki peranan penting dalam menentukan penerimaan suatu produk pangan (Adawiyah et al., 2009). Hasil uji sidik ragam menunjukkan bahwa perbandingan konsentrasi mocaf-dekstrin, karaginan, $\mathrm{KCl}$ dan interaksi yang terjadi antara perbandingan konsentrasi mocafdekstrin dan karaginan, mocaf-dekstrin dan $\mathrm{KCl}$, karaginan dan $\mathrm{KCl}$ tidak memberikan pengaruh yang nyata terhadap penerimaan panelis terhadap aroma puding $(p>0,05)$.

Metode pengukuran tekstur telah banyak dilakukan untuk memperoleh struktur suatu bahan pangan. Pengukuran tekstur suatu bahan pangan dapat dilakukan baik secara fisik, kimia dan sensori. Pengukuran tekstur secara sensori dapat dilakukan secara langsung dengan menggunakan panelis. Pengujian tekstur tidak hanya melibatkan indra peraba saja, melainkan indra penglihatan dan pendengaran mempunyai peran besar dalam mengevaluasi tekstur suatu produk pangan. Hasil uji sidik ragam menunjukkan bahwa perbandingan konsentrasi mocaf-dekstrin dan $\mathrm{KCl}$ serta interaksi yang terjadi antara perbandingan konsentrasi mocaf-dekstrin dan $\mathrm{KCl}$ memberikan pengaruh yang nyata terhadap penerimaan panelis terhadap tekstur puding $(p<0,05)$, sedangkan perbandingan konsentrasi karaginan dan interaksi konsentrasi mocaf-dekstrin dan karaginan serta interaksi konsentrasi karaginan dan $\mathrm{KCl}$ tidak memberikan pengaruh yang nyata terhadap penerimaan panelis terhadap tekstur puding $(p>0,05)$. Peningkatan konsentrasi mocaf dekstrin memberikan pengaruh yang nyata terhadap tekstur puding yang dihasilkan dimana peningkatan jumlah mocaf dekstrin yang digunakan menyebabkan penurunan tingkat kesukaan panelis terhadap puding yang dihasilkan.

Rasa merupakan persepsi dari sel pengecap yang meliputi rasa asin, manis, asam dan pahit yang diakibatkan oleh bahan yang terlarut dalam mulut. Rasa merupakan atribut sensori yang tidak dapat dilepaskan dari keseluruhan cita rasa produk pangan.
Menurut Soekarto (1985), rasa merupakan faktor yang sangat menentukan pada keputusan akhir konsumen untuk menerima atau menolak suatu makanan, walaupun parameter yang lain baik, tetapi jika rasanya tidak enak atau tidak disukai maka akan ditolak oleh konsumen. Hasil uji sidik ragam menunjukkan bahwa perbandingan konsentrasi mocaf-dekstrin, karaginan, $\mathrm{KCl}$ dan interaksi yang terjadi antara perbandingan konsentrasi mocaf- dekstrin dan karaginan, mocafdekstrin dan $\mathrm{KCl}$, karaginan dan $\mathrm{KCl}$ tidak memberikan pengaruh yang nyata terhadap penerimaan panelis terhadap rasa puding $(p>0,05)$. Pembuatan puding pada penelitian ini menggunakan perisa yang sama untuk semua perlakuan sehingga rasa yang dihasilkan cenderung sama antara satu dengan yang lainnya.

\section{KESIMPULAN}

Perbandingan kappa dan iota karaginan yang cocok untuk digunakan dalam pembuatan tepung puding instan yaitu $1: 1$ yang menghasilkan produk dengan nilai kekuatan gel yang menyerupai kekuatan gel dari tepung puding instan komersial. Perbandingan konsentrasi karaginan, mocaf-dekstrin dan $\mathrm{KCl}$ dalam formulasi tepung puding instan tidak memberikan pengaruh yang nyata terhadap kekuatan gel maupun karakteristik sensori kenampakan, aroma dan rasa dari puding yang dihasilkan.

Formulasi tepung puding instan memberikan pengaruh yang nyata terhadap karakteristik tekstur puding yang dihasilkan. Berdasarkan kekuatan gel dan karakteristik sensori (kenampakan, aroma, tekstur, dan rasa) didapatkan perlakuan terbaik yaitu penggunaan karaginan $1,23 \%$, perbandingan tepung

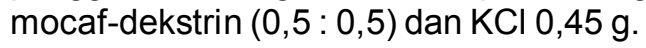

\section{DAFTAR PUSTAKA}

Adawiyah, R., Dede \& Waysima. (2009). Buku Ajar Evaluasi Sensori Untuk Pangan edisi 1. Departemen IImu dan Teknologi Pangan. Fakultas Teknologi Pertanian IPB. Bogor.

Angka, S.L., \& Suhartono, M.T. (2000). Bioteknologi Hasil Laut. Cetakan Pertama, Pusat Kajian Sumberdaya Pesisir dan Lautan, IPB.

Anonim. (2006). Teknologi Modifikasi Pati. hattp:// ebookpangan.com//teknologi_modifikasi_pati. Diakses pada tanggal 20 Desember 2010

Anonim. (2009). Puding yang Menggiurkan. http:// www. halalguide.info/2009/04/20 Puding-yangmengiurkan/. Diakses pada tanggal 15 januari 2011.

Anonim. (2013). Indonesia genjot produksi rumput laut 10 juta ton. http://www.investor.co.id/agribusiness/ 
indonesia-genjot-produksi-rumput-laut-10-juta-ton/ 52680. Diakses pada tanggal 8 April 2013.

[AOAC] Association of Official Analytical Chemyst. (1999). Official Methods of Analysis the Association. 15th. Ed. AOAC. Virginia: AOAC Inc. Arlington.

Apriyantono, A.D., Fardiaz, D., Puspitasari, N., Sodarnawati, \& Budiyanto S. (1989). Analisis Pangan. Pusat Antar Universitas Pangan dan Gizi, IPB, Bogor

Basmal, J., Syarifudin, \& Ma'ruf, W.F. (2003). Pengaruh konsentrasi larutan potassium hidroksida terhadap mutu kappa-karaginan yang diekstraksi dari Eucheuma cottonii. Jurnal Penelitian Perikanan Indonesia. 11(8): 95-103.

Basmal, J., Suryaningrum, T.D., \& Yennie, Y. (2005). Pengaruh konsentrasi dan rasio larutan potasium hidroksida dan rumput laut terhadap mutu karaginan kertas. Jurnal Penelitian Perikanan Indonesia. (11): 29-38.

Basmal, J., Sedayu, B.B., \& Utomo, B.S.B. (2009). Effect of $\mathrm{KCl}$ on the precipitation of carrageenan from E.cottonii extract. Journal of Marine and Fisheries Postharvest and Biotechnology-special Edition. Balai Basar Riset Pengolahan Produk dan Bioteknologi Kelautan dan Perikanan. Departemen Kelautan dan Perikanan, Jakarta. p. 51-58.

Campo, V.L., Kawano, D.F., da Silva Jr., D.B., Carvalho, I. 2009. Review Carrageenans: Biological properties, chemical modifications and structural analysis. Carbohydrate Polymers. 77: 167-180.

De Ruiter, G.A. \& Rudolph, B. (1997). Carrageenan Biotechnology. Trends in Food Science \& Technology. 8: 389-395.

Dickinson, E. (2003). Hydrocolloids at interfaces and the influence on the properties of dispersed systems. Food Hydrocolloids. 17(1): 25-39.

Diharmi A., Fardiaz, D., Andarwulan, N., dan Heruwati, E.S. (2011). Karakteristik karagenan hasil isolasi Eucheuma spinosum (alga merah) dari perairan Sumenep Madura. Jurnal Perikanan dan Kelautan. 16(1): 117-124.

Distantina, S., Fadilah, Danarto, Y.C., Wiratni, \& Fachrurozi M. (2009). Pengaruh kondisi proses pada pengolahan Eucheuma cottonii terhadap rendemen dan sifat gel karaginan. Ekuilibrum (8): 35-40.

FMC Corp, Marine Colloids. (1977). Carrageenan. Marine Colloid Monograph Number One. Springfield New Jersey, USA: Marine Colloid Division FMC Corporation.

Food and Agriculture Organization (FAO). (2007). Carrageenan. Prepared at the 68th JECFA and Published in FAO JECFA Monographs 4. p. 1-6.

Food Chemical Codex (FCC). 1981. Carrageenan. National Academy Press Washington. p. 74-75.

Glicksman, M. 1983. Food Hydrocolloids. CRS Press, Inc. Florida. Volume II: 74-83

Hakim, A.R., Wibowo, S., Arfini, F., \& Rosmawaty, P. (2011). Pengaruh perbandingan air pengekstrak, suhu presipitasi dan konsentrasi kalium klorida $(\mathrm{KCl})$ terhadap mutu karaginan. Jurnal Pascapanen dan Bioteknologi Kelautan dan Perikanan. 6(1): 1-11.

Hartomo, A.J. \& Widiatmoko, M.C. (1993). Emulsi dan Pangan Instan Berlesitin. Andi Offset, Yogyakarta.

Hustiany, R. (2006). Modifikasi Asilasi dan Suksinilasi Pati Tapioka sebagai Bahan Enkapsulasi Komponen Flavor. Disertasi Pasca Sarjana. Institut Pertanian Bogor, Bogor.

Hilliou Loic, Fábio D.S. Larotondab, Pedro Abreuc, Maria $H$. Abreud,e,f, Alberto M. Serenob, \& Maria P. Goncalves. (2012). The impact of seaweed life phase and postharvest storage duration on the chemical and rheological properties of hybrid carrageenans isolated from Portuguese Mastocarpus stellatus. Carbohydrate Polymers. 87: 2655-2663.

Imeson, A.P. (2000). Carrageenan. In Phillips, G.O. and Williams, P.A. (eds.). Handbook of Hydrocolloids. Cambridge. UK: Woodhead Publishing Limited. pp. 87-102.

Istini, S. \& Zatnika, A. 1991. Optimasi proses semirefine carrageenan dari rumput laut Eucheuma cottonii. Di dalam: Teknologi Pasca Panen Rumput Laut. Prosiding Temu Karya IImiah 11-12 Maret 1991. Jakarta Departemen Pertanian. pp. 86-95.

Novianti, L. (2003). Pemanfaatan Kombinasi Tipe Kappa dan lota Karaginan Setengah Jadi (semi refined carrageenan) sebagai Pengental dan Stabilisator pada Formula Krim Kulit. Skripsi. Fakultas Matematika dan IImu Pengetahuan Alam Universitas Indonesia. Depok.

Pereira, L., Amado, A.M., Critchley, A.T., Van De Velde, F., \& J.A. Ribeiro-Claro, P. (2009). Identification of selected seaweed polysaccharides (phycocolloids) by vibrational spectroscopy (FTIR-ATR and FTRaman). Food Hydrocoloids. 23: 1903-1909.

Purnama, R.C. (2003). Optimasi Proses Pembuatan Karaginan dari Rumput Laut Eucheuma cottonii. Skripsi. Fakultas Teknologi Hasil Perikanan. IPB, Bogor.

Selby, H.H. \& Whistler, R.L. (1993). Industrial Gums: Polysaccharides and Their Derivatives (3rd ed.). In Whistler, R.L. and BeMiller, J.N. (eds.). Academic Press, London. pp. 87-103.

Soekarto, S.T. (1985). Penilaian Organoleptik. Bharata Karya Aksara, Jakarta.

Steel, R.G.D. \& Torrie, J.H. (1993). Prinsip dan Prosedur Statistika, Suatu Pendekatan Biometrik. Alih Bahasa N. Soemantri. PT. Gramedia Pustaka Utama, Jakarta. p. 377-398.

Subaryono, Utomo, B.S.B., Wikanta, T., \& Satriyana, N. (2003). Pengaruh penambahan iota karaginan pada ekstraksi agarosa dari agar-agar menggunakan cetylpiridinum klorida. J. Penel. Perikanan Indonesia. 9(5): $1-5$.

Suryaningrum, T.D. (1988). Kajian Sifat-Sifat Mutu Komoditas Rumput Laut Budidaya Jenis Eucheuma cottonii dan Eucheuma spinosum. Tesis. Program Pascasarjana Institut Pertanian Bogor, Bogor. 181 pp.

Trcková, J., Stetina, J., \& Kánsky, J. (2004). Influence of protein concentration on rheological properties of 
carrageenan gels in milk. International Dairy Journal. 14: 337-343.

Van De Velde, F., Knutsen, S. H., Usov, A. L., Rollema, H. S., \& Cerezo, A. S. (2002). $1 \mathrm{H}$ and $13 \mathrm{C}$ high resolution
NMR spectroscopy of carrageenans: Application in research and industry. Trends in Food Science \& Technology. 13: 73-92. 